\section{COMING EVENTS}

King's Fund Centre-Day conference "Problem of Communication Between the Overseas Docto and his Patient," 21 October, London. Details and application forms from Miss M D Hinks, Research Officer, King's Fund Centre, 24 Nutford Place, London W1H 6AN.

Royal College of Physicians of LondonClinicopathological conference, 30 October, London. Details from Assistant Secretary of RCP 11 St Andrew's Place, Regent's Park, London NE1 4LE. (Tel 01-935 1174).

North-east Thames Region Society of Community Medicine-Day symposium, "Vaccination and Immunisation," 31 October, London Details from Dr W T Orton, District Community Physician, Haringey Health District, Mountford House, the Green, London N15 4AN. (Tel. 01-808 1081, ext 113.)

Manchester Medical Society-Details and copies of the October programme are now available from the Honorary Secretary, Manchester Medical Society, the University, Manchester M13 9PL.

The Chest and Heart Association-Day conference, "Bronchitis and Asthma Today," 4 November, London. Details from Miss Hilda V Walsh, Chest and Heart Association, Tavistock House North, Tavistock Square, London WC1H 9JE. (Tel 01-387 3012.)

Edinburgh Postgraduate Board for Medicine - The programme of courses 1975-6 is now available from the Postgraduate Dean, $\mathrm{Mr} \mathrm{J} \mathrm{M}$ Matheson, Edinburgh Postgraduate Board for Medicine, Pfizer Foundation, Hill Square, Edinburgh EH8 9DR. (Tel 031-667 1011 ext 2502/3.)

Hunterian Society-The programme for $1975-6$ is now available from Dr Anne Jepson, 46 Brondesbury Park, London NW6.

Gwent Postgraduate Medical Centre-Details and copies of the programme 1975-6 are now available from the Postgraduate Secretary, Gwent Postgraduate Medical Centre, Royal Gwent Hospital, Newport, Gwent. (Tel Newport 52244.)

Midland Thoracic Society-Copies of the programme 1975-6 are now available from the Honorary Secretary, Dr C W Edwards, Department of Pathology, East Birmingham Hospital, Birmingham B9 5ST.

University of Dundee-Details and copies of the programme of postgraduate medical education, 1975-6, are now available from Dr Hamish Watson, Postgraduate Dean and Director of Postgraduate Medical Education, Faculty of Medicine, the University, Dundee DDl 4HN. (Tel 038223181 ext 412.)

Nuffield Department of Orthopaedic Surgery - Postgraduate course on "The Basic Sciences of the Musculo-Skeletal System," October-December Oxford. Details and copies of the programme are available from the Nuffield Department of Orthopaedic Surgery, Nuffield Orthopaedic Centre, Headington, Oxford.

Bateman Centre for Postgraduate Medical Studies-Details and copies of the programme 1975-6 are now available from the Postgraduate Tutor, Birch Hill Hospital, Rochdale OL12 9QB. (Tel 0706 78294, ext 253.)

Institute of Urology-Symposium "Gynaecological Urology," 7-8 November, London. For details see advertisement at $\mathrm{p} x \mathrm{v}$.

"Entertainment Noise as a Hazard to Hearing"-Conference held by the Institute of Acoustics, 29 October, London. Details from the Institute, 47 Belgrave Square, London SW1X 8QX. (Tel 01-235 6111.)

BMA and MIA Music Society-Rehearsals of Christmas carols begin on Tuesday, 7 Octo- ber, $1.15 \mathrm{pm}$, BMA House. New members are very welcome; an average singing voice is required.

\section{SOCIETIES AND LECTURES}

\section{Saturday, 4 October}

Midland
Medical Institute, $2.30 \mathrm{pm}$, ordinary meeting : The management of infective endocarditis.

\section{Monday, 6 October}

INSTITUTE OF LARYNGOLOGY AND OTOLOGY-5.30 $\mathrm{pm}$, clinicopathological conference.

Mr Selwyn F OF SURGEONS OF ENGLAND-6 pm

\section{Tuesday, 7 October}

RoYai. COL.t.ege OF Surgeons OF ENGland-6 pm
$\mathrm{Mr} \mathrm{P}$ M Aichroth: Internal derangements of the knee.

\section{Wednesday, 8 October}

Royal. COI.lege of SURGEONS OF EDINBURGH-A $\begin{array}{lllll}\text { University of Liverpool, } 4.30 & \mathrm{pm}, & \mathrm{Mr} & \mathrm{W} & \mathrm{R} \\ \text { IVyldesley: Oral leukoplakia. } & \end{array}$ CARDIOTHORACIC INSTITUTE-5 pm, Mr $\mathbf{R}$ Pitts

Crick: Ocular sarcoidosis.
Royal. FreE Hospital $-5 \mathrm{pm}$, Protessor David Todd (Hong Kong): Alpha-thalasseme

ROYAI. COLIEGE OF SURGEONS OF ENGLAND-6.15 pm Mr M S Owen-Smith: Gunshot wounds. genesis Imperfecta: Biological considerations. pm, Dr Roger Smith: Osteogenesis imperfecta.

\section{Thursday, 9 October}

Royal College of SURgeons of ENGland-6 pm Mr P S London: Management of multiple trauma.
MEDICo-LEGAL. SOCIETY.-8.15 pm, presidential address.

Friday, 10 October

INSTITUTE OF UROL.OGY-12.30 pm, Professor J J Iglesias (New Jersey): The use of a new suction Royal COLI.EgE OF SURGeons of ENGLAND-6 pm $\mathrm{Mr} J$ S P Wilson: The scope of surgery in the

MEDICAL WOMEN'S FEDERATION CARDIFF AsSOCIA ToN At Bear Hotel, Cowbridge, 7.30 for $8 \mathrm{pm}$

\section{B.M.A. NOTICES}

\section{Diary of Central Meetings}

\begin{tabular}{|c|c|}
\hline & OCTOBER \\
\hline $\begin{array}{l}7 \text { Tues } \\
9 \text { Thurs }\end{array}$ & $\begin{array}{l}\text { Armed Forces Committee, } 2 \mathrm{pm} \text {. } \\
\text { Scottish Council ( } 7 \text { Drumsheugh Gardens, } \\
\text { Edinburgh EH3 7OPP) } 1045 \text { am. }\end{array}$ \\
\hline $\begin{array}{l}9 \text { Thurs } \\
10 \text { Fri } \\
16 \text { Thurs } \\
16 \text { Thurs }\end{array}$ & $\begin{array}{l}\text { Education Subcommittee (GMS), } 2 \text { pm. } \\
\text { Charities Committee, } 10.30 \mathrm{am} \text {. } \\
\text { General Medical Services Committee } 10 \mathrm{am} \text {. }\end{array}$ \\
\hline 16 Thurs & $\begin{array}{l}\text { Anaesthetists Subcommittee (CCHMS), } \\
2 \mathrm{pm} \text {. }\end{array}$ \\
\hline 21 Tues & Joint Consultants Committee (Royal College \\
\hline $\begin{array}{l}22 \text { Wed } \\
23 \text { Thurs }\end{array}$ & $\begin{array}{l}\text { of Surgeons, London WC2), } 9.30 \text { am. } \\
\text { Council, } 10 \text { am. } \\
\text { Scottish Committee for Community Medi- } \\
\text { cine ( } 7 \text { Drumsheugh Gardens, Edinburgh } \\
\text { EH3 } 7 Q P \text { ) } 10.45 \text { am. }\end{array}$ \\
\hline $24 \mathrm{Fri}$ & $\begin{array}{l}\text { Working Party on Services for the Elderly } \\
\text { (Board of Science and Education), } 10.30 \text { am. }\end{array}$ \\
\hline $29 \mathrm{~W}$ & $\begin{array}{l}\text { Compensation and Superannuation Com- } \\
\text { mittee, } 10.30 \mathrm{am} \text {. }\end{array}$ \\
\hline
\end{tabular}

\section{Branch and Division Meetings to be Held}

Members proposing to attend meetings marked ${ }^{*}$ are
asked to notify in advance the honorary secretary concerned.

Bath District Division-At postgraduate centre Royal United Hospital, Bath, Tuesday, 7 October. 8 pm, business meeting.

6 Ourh m Division-At Dryburn Hospital, Monday, (Preceder by pm, Mr J Bell:

East Yorkshire Branch-At postgraduate centre Hull Royal Infirmary, Wednesday, 8 October, 7.30

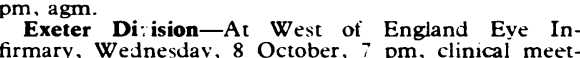
firmary, Wednesday, 8 October, $7 \mathrm{pm}$. clinical meeting: "Diabetes and the eye."
Gloucestershire Branch-At Ca-Iton Hotel, Chelten ham, Thursday, 9 October, $7.15 \mathrm{pm}$ business meeting and presidential address.* (Followed by supper, 8.30 pm.) G'ackenwich Division-At 73 Mycenae Road, cheece and wine party.* ${ }^{*}$ Harrow Hospital, Tuesday October, 8.45 pm, agm.
Manchester Division-At Boyd House, Tuesday October, 8 pm, agm North Warwickshire Division-At Chase Hotel (n) 7.30 for $8.30 \mathrm{pm}$. Rotherham Division- * (Guests are invited.) Sheffield, Wednesday, 8 October, 8.00 for $8.30 \mathrm{pm}$ annual dinner and dance.* Scunthorpe Division-At Scunthorpe General
Hospital, Tuesday, 7 October, 8 pm, special general meeting.

Woking and Chertsey Division-At Botleys Park Hospital, Wednesday, 8 October, $8.30 \mathrm{pm}$, genera

meeting.
Worcester and Bromsgrove Division-At Ronks-
wood Hospital, Saturday, meeting to discuss divisional visit to Holland and proposed return visit of Dutch colleagues, and socia evening.*

\section{UNIVERSITIES AND COLLEGES}

ROYAL COLLEGE OF OBSTETRICIANS AND GYNAECOLOGIS'TS

At a meeting of the council held on 27 September the following assumed office for the ensuing year: Professor C J Dewhurst (president), Dr R Murdoch (senior vice-president), Mr T L T Lewis (junior vice-president), Mr G D Pinker (honora
Mr R I Booth (honorary secretary).

\section{APPOINTMENTS}

City and East london Area Health authority (TEACHING)- The following consultants have been Britton (nuclear medicine); $\mathrm{Dr} M \mathrm{M}$ Wright (rheumatology and rehabilitation); Dr Rosalyn M Reid (radiology).

Ealing, Hammersmith and Hounslow Area Health Authority ('Teaching) - Mr M. Grippaudo (consultant ear, nose, and throat surgeon).

Hampshire AREa Health Authority (Teaching)Mr C J Smart, consultant urologist.

NORTH WESTERN RHA-The following consultants have been appointed: $\operatorname{Dr} S \mathrm{R}$ Tangye (psychiatry R Gupta (ophthalmology). Wessex RHA-Dr D W Hide (consultant paedia trician).

\section{Corrections}

The mite and childhood asthma

We regret that owing to a printing error the signature of Dr D G Wraith at the foot of this letter (27 September, p 766) was incorrectly spelt.

Prevention of contact dermatitis

We regret that reference 2 in this article (6 September, p 557) was omitted. This should have read Wilkinson, D S, Contact Dermatitis, 1975, 1, 11.

\section{NHS superannuation}

In paragraph 29 of this article on NHS superannuation (20 September, p 720) the date in the third line should have read: "30 June 1950." We apologise for this error.

\section{Notice to authors}

When original articles and letters for publication are not submitted exclusively to the British Medical fournal this must be stated. For detailed instructions to authors see page 6 of this issue.

Correspondence on editorial business should be addressed to the Editor, British Medical fournal, BMA House, Tavistock Square, London WC1H 9JR. Telephone: 01-387 4499. Telegrams: Aitiology, London WC1. Communications will not be acknowledged unless a stamped addressed postcard is enclosed.

Authors wanting reprints of their articles should notify the Publishing Manager, BMA House, Tavistock Square, WC1H 9JR, on receipt of proofs.

\section{British Medical Journal 1975}

All Rights Reserved. No part of this publication may be reproduced, stored in a retrieval system, or transmitted, in any form or by any means, electronic, mechanical, photocopying, recording or otherwise, without the prior permission of the British Medical fournal. 